\title{
ANALYSIS OF OPINIONS AND ATTITUDES OF LOCAL COMMUNITIES AND TOURISTS ON THE QUALITY OF TOURISM SUPPLY AT THE VRANICA MOUNTAIN
}

\author{
Amra Banda ${ }^{1}$ \\ Amina Sivac ${ }^{2}$ \\ Vesna Babić-Hodović ${ }^{3}$ \\ Maja Arslanagić-Kalajdžić ${ }^{4}$
}

\begin{abstract}
Bosnia and Herzegovina was a symbol of winter tourism in the former Yugoslavia, and it still has a significant tourism potential due to its rich natural and cultural heritage, advantageous of geographical position and proximity to the emissive tourist markets. Mountain Vranica is a popular tourist destination that provides many opportunities for the development of various forms of tourism throughout the whole year. Vranica includes central parts of Bosnia and Herzegovina and belongs to the area of the Central Dinarides, as a part of so called Vranica rayon. The variety and attractiveness of the geological structure, relief, hydrological phenomena, flora and fauna, as well as the attractiveness of the landscape, are the primary factors for the development of tourism in this area. However, despite the significant tourism potential, tourism is insufficiently recognized in this area. The aim of this paper is to determine the characteristics of tourism trends, the impact of tourism development on the local community, as well as differences in the perception of tourist motives of Vranica by the local community and tourists. The research is based on an analysis of the results of direct surveys conducted during 2016 at multiple locations on Vranica, on a sample of 210 tourists and residents (106 local residents and 104 tourists). The survey included respondents older than 18 years and statistical analysis was conducted in SPSS. Its results can be used for better identification of visitors' profile, and as a starting point in conception of tourist supply of higher quality in the future, with greater integration of local communities and residents' opinion in the process of tourism planning of this area.
\end{abstract}

Key words: Vranica, tourism supply, tourists, local communities, tourism development.

\section{INTRODUCTION}

Tourism as a phenomenon is usually perceived as a tool for an economic development of the local community. This is especially visible through various factors which may

\footnotetext{
${ }^{1}$ Senior Teaching Assistant, Department of Geography, Faculty of Science, University of Sarajevo, Sarajevo, Bosnia and Herzegovina. e-mail: amra.banda@pmf.unsa.ba

${ }^{2}$ Teaching Assistant, Department of Geography, Faculty of Science, University of Sarajevo, Sarajevo, Bosnia and Herzegovina. e-mail: amina.sivac@pmf.unsa.ba

${ }^{3}$ Full Professor, School of Economics and Business, University of Sarajevo, Sarajevo, Bosnia and Herzegovina. e-mail: vesna.babic-hodovic@efsa.unsa.ba

${ }^{4}$ Assistant Professor, School of Economics and Business, University of Sarajevo, Sarajevo, Bosnia and Herzegovina. e-mail: maja.arslanagic@efsa.unsa.ba
} 
improve quality of life in local communities, such as employment and investments opportunities, tax revenues, building of accommodation service and restaurants, development of festivals, and outdoor recreation opportunities (Kandampully 2000; Andereck et al. 2005; Kiriakidou and Gore 2005). However, it can also lead to negative effects on quality of life in local communities, such as cost of living, parking problems, increase on traffic, increase of crime and changes in hosts' lifestyle (McCool and Martin 1994; Brunt and Courtney 1999; Tosun 2002).

Since the 1970s, attitudes and perceptions of local communities toward the impact of tourism are broadly analyzed by managers of the tourism industry, spatial and tourism planners, policy makers and academicians (Young 1973; Doxey 1975; Perdue et al. 1987; Lankford 1994; Jurowski et al. 1997; Andereck and Vogt 2000; Andereck et al. 2005). There is no doubt that residents' perceptions and attitudes toward any local tourism development policy should also be analyzed and thoroughly studied (Aguiló and Roselló 2005; Ritchie and Inkari 2006). This is the only way for understanding the reasons why the residents would support or not the tourism activity and furthermore to decrease negative impacts of tourism development (Vargas-Sanchez et al., 2011).

Considering the fact that tourism relies upon the goodwill of the local community, their support is essential for its development, successful operation, and sustainability of the tourism activity in the long term (Ap 1992; Garrod and Fyall 1998; Sheldon and Abenoja 2001; Aguiló and Roselló 2005; Vargas-Sánchez et al. 2011). In fact, the sense of residents' community attachment not only influences residents' perceptions of the impacts of tourism (Sheldon and Var 1984; Um and Crompton 1987; McCool and Martin 1994), but also the relationship between the local community and tourists. Therefore, if residents' attitudes are sympathetic towards the tourism impact, they will probably support increased local tourism development and they will be more hospitable with tourists. According to that, it is important to recognize that tourists are more attracted by destinations with friendly and hospitable residents (Fallon and Schofield 2006). In this context, the local community must be involved in the process of tourism planning and its development in order to obtain long-term development of the destination. Accordingly, the primary aim of tourism planners should be to gain a thorough knowledge of the characteristics of the destination which residents want to preserve and protect. The reason is that the understanding of residents' attitudes towards the impacts of tourism implies the knowledge of relations between residents and their community (Brehm et al. 2004). So far, not many studies were conducted with the aim to analyze the relationship between residents' community attachment and sociodemographic characteristics and perceptions of impacts, benefits and support for tourism development (Lee et al. 2010A). One of these studies was conducted by (Lee et al. 2010B), who analyzed how residents' perceptions affect the level of residents' benefits and consequently their support to tourism development in two different gambling communities.

Teye et al. (2002) emphasize relationship between tourists and local residents, importance of tourism development for the local community, the area's level of tourism 
development, for how long residents have been living in the community and the distance between the place where they live and the tourist center.

The aim of this paper is to determine the impact of tourism development on the local community, as well as differences in the perception of tourist motives by the local community and tourists. The purpose of this paper is to determine and assess how residents' perception towards the tourism development is affected by residents' perception of tourism impacts on economic, environmental and socio-cultural aspects.

One of the objectives of this paper is to evaluate tourists' attitudes towards Vranica mountain tourist destination, i.e. to evaluate the level of tourists' satisfaction with tourism attractions, activities and services. Also important objective is to analyze connection between travel motivational factors and tourists' satisfaction levels. This paper aims to assess tourists' attitude towards tourism development on Vranica mountain, which should assist in understanding strong and weak points of the exsisting tourism supply.

The dataset comes from a survey on residents' attitudes and perceptions towards tourism development in Vranica, mountain located in the Central Bosnia. The research is based on an analysis of the results of direct surveys of tourists and residents on the mountain Vranica on a sample of 210 respondents during 2016. To reach our aims we conducted a descriptive analysis of the data in order to estimate the determinants of the residents' attitudes toward tourism policy.

\section{LITERATURE REVIEW}

\section{Tourism impact}

As mentioned before, academics start discussion and research about community reactions to the local development of tourism since the 1970 s, precisely with the papers of Young (1973) and Doxey (1975). Several studies displayed the fact that tourism impacts on the destination are economic, environmental, and socio-cultural (among others Long et al. 1990; Andereck and Vogt 2000; Andereck et al. 2005; Dietrich and Garcia-Buades 2008; Ogorelc 2009; Vargas-Sánchez et al. 2009; Deery et al. 2011; Ozturk, Ozer and Caliskan 2015). An extensive review of the recent research studies related to tourism impacts on the destination are found in the work of Easterling (2004) and, more recently, in Deery et al. (2011). The literature review suggests that each tourism impact category includes positive and negative effects and, sometimes, local communities' perceptions are contradictory.

As the most positive side effect of tourism development recognized by the local community is economic development, which includes an increase of the employment (Balaguer and Cantavella, 2002; Samimi et al., 2011; Zaei and Zaei, 2013), local economy development, increased investments and economic diversification (Liu and Var 1986; Dietrich and Garcia-Buades 2008; Vargas-Sánchez et al. 2009), additional 
income, improved local and state tax revenues and increased quality of life in general (Haralambopoulos and Pizam 1996; Huh and Vogt 2008). On the other hand, local community seems to perceive an increase in the cost of living, for example in prices of goods and services, and an unequal distribution of the economic benefits as the biggest negative impact of tourism development (Liu and Var 1986; Haralambopoulos and Pizam 1996; Andereck and Vogt 2000; Andriotis 2005).

An environment is a central theme in tourism related papers since the 1980 s and it continues to be an attractive topic in a time when the global policy is aimed at geoecological problems, such as pollution, depletion of natural resources and deforestation. The potential of tourism activities in achieving the objectives of environmental preservation and conservation have been widely studied (Baysan, 2001; Budeanu, 2007; Schneider, 2007; Ramdas and Mohamed 2014). A study by Liu and Var (1986) demonstrates that about half of the interviewed residents are in favor with tourism because it is a tool to obtain more parks and recreation areas, to improve the quality of roads and public facilities, and it does not contribute to ecological decline (Pedrana, 2013). Doswell (1997) suggests that tourism is a phenomenon which stimulates environmental conservation and improvement. On the other hand, some studies suggest that tourism causes traffic and pedestrian congestion, parking problems, disturbance and destruction of biodiversity, air and water pollution (McCool and Martin 1994; Brunt and Courtney 1999; Jurowski and Gursoy 2004; Andereck et al. 2005; Jago et al. 2006; Frauman and Banks 2011). Therefore, a number of studies regarding sustainable tourism development have been made with an aim to analyze the combination of environmental conservation, local people's livelihood and economic benefits of tourism (Ogorelc 2009).

Other studies suggest that tourism impacts also have various socio-cultural effects. Dogan (1989), for example, suggests that tourism causes changes in habits, daily routines, social lives, beliefs, and values, while Haralambopoulos and Pizam (1996), Andereck et al. (2005), Dietrich and Garcia-Buades (2008) claim that an uncontrolled tourism development causes modification of traditional cultures, an increase in crime and in costs of accommodation. Inadequate tourism development can lead to increased stress of the members of local community and have a negative impact on destinations' socio-cultural (Brunt and Courtney, 1999; Jovičić, 2011) and physical-geographical characteristics. Perdue et al. (1991) in particular focused on the geographic relocation of residents due to the increase in second home owners. Meanwhile, some authors claim that tourism can also produce some positive socio-cultural effects, such as an increase in the community services, recreational and cultural facilities, cultural events and cultural exchanges (Liu and Var 1986; Perdue et al. 1991; McCool and Martin 1994; Gilbert and Clark 1997; Brunt and Courtney 1999; Jovičić, 2011; Sari, 2012). Finally, the academic literature (among others Goodwin, 2006) focused also on the role which tourism plays in terms of social and cultural preservation, revitalization of ethic culture, and promotion of domestic products, arts and crafts with an increasing concern about the ethical behavior of both, local communities and tourists. 


\section{Determinants of residents' perception of tourism impact}

Due to rapid tourism development at the global level since the 1980s, local communities are no longer a homogenous group in terms of their perception of tourism impacts. Their heterogeneity is visually shown through the profit generated by tourism those residents who gain more benefits than costs from tourism view its impacts positively, others view them negatively.

An academic literature has identified a number of different variables influencing residents' perceptions of tourism impacts (Andereck et al., 2005). For example, spatial and tourism planners are interested in knowing which are these variables at the specific location and they are especially focused on recognizing which of them are of the biggest importance on that particular destination. This is all analyzed in order to gain residents' support to actual and future local tourism development policies.

Most of the variables suggested by the academic literature are linked to the sociodemographic and economic profile of the residents, such as age, gender, and level of income (Dogan, 1989; Haley et al. 2005; Sharma and Dyer, 2009), or to their attachment and relationship to the community and connection with tourists.

Some studies have also examined the role of the community attachment value (Andereck et al. 2005; Woosnam et al., 2009; Ryan and Gu, 2010), aiming to describe the residents' relationship to the local area. The community attachment is defined as the "extent and pattern of social participation and integration into community life, and sentiment or affect toward the community" (McCool and Martin 1994). This attachment was measured in a variety of ways, such as the place of birth and raise, and/or length of living in the community (Sheldon and Var 1984; Um and Crompton 1987; Lankford and Howard 1994; Jurowski et al.1997; MeGehee and Andereck 2004). However, the relationship between community attachment and tourism impacts is in a way controversial, as some studies suggest that the longer an individual resides in a community, the more negative is the attitude towards tourism development (Um and Crompton 1987; Lankford and Howard 1994). On the other side there are authors emphasizing that this relation can't be confirmed in every situation (McCool and Martin 1994; Gursoy et al. 2002; McGehee and Andereck 2004; Andereck et al. 2005).

On the other hand, some authors disagree with these statements and conclude that residents being economically dependent on tourism find more negative association with tourism manifesting this in a strong negative attitude (Williams and Lawson 2001; Teye et al., 2002). On the same argument, we can observe that residents' perception of tourism impacts is influenced by the possibility of having an economic gain (Haralambopoulos and Pizam 1996; Gilbert and Clark 1997; Brunt and Courtney 1999; Teye et al. 2002; McGehee and Andereck 2004). Andereck et al. (2007) suggest that the more residents have knowledge about tourism and have intensive contact with tourists, the more they have a positive perception of the benefits gained through tourism. Contrariwise, Lankford and Howard (1994) did not find any significant relation between community members' attitudes and the degree of the contact with tourists. 


\section{Tourist attitude, motivation and satisfaction}

A review of the published literature on tourist motivation and attitudes highlights the existence of a broad spectrum of characteristics and personal attitudes toward tourism. Different researchers provided various "attitude" definitions and some of them are meaningful for this research: "an attitude is a trend, pro or con, to an environmental element, which becomes a positive or negative value" (Bogardus, cited in Albu and Nicolau, 2010). Attitude can also be defined as a "sustainable organization of beliefs towards an object or a situation that predisposes an individual to respond in a preferential manner." (Albu and Nicolau, 2010).

According to Jafari (2001) tourists' perceptions and attitudes are significant for tourism development which influence local community and their economy, cultures and environments as well as their intention to revisit the destination. Tourists attitude is important for tourism destinations because more positive attitude from tourists towards destination can lead to tourist satisfaction.

Tourists attitude toward the environment in destination can be defined as a measure of how people would like to experience the landscape according to their personal preferences for cultural, social, and environmental aspects. (Kaltenborn et al., 2011).

Understanding tourist motivations is crucial for tourism development in particular destination. For example, Timothy and Boyd (2003) indicated that people visit heritage places to enhance learning, satisfy curiosity, grow spiritually, relax and get away from daily routine. Tourism researchers define tourist satisfaction as the results of the comparison between "a tourist's experience at the destination visited and the expectations about the destination" (Sukiman et al., 2013).

Number of reasons such as tourist attractions, provided services, tourist infrastructure, local cuisine, hospitality of local community, security, cleanliness, environment and accessibility can make tourists satisfied with their journey (Handszuh, 1995; cited in Salleh et al., 2013).

Literature (Nash et al. 2006; Xia et al. 2009) on tourism satisfaction reveals that accommodations are important for both competitiveness of the destination and the tourist satisfaction itself. Presence and quality of tourist signs is often an underestimate attribute within tourism satisfaction, but for the purpose of this research we decide to include this element, since it can produce dissatisfaction. Value for money is commonly considered "one consistent satisfaction attribute" (Yu and Goulden, 2006). Hospitality of local community is one of the principal destination attributes that leads to tourist satisfaction (Jenkins, 1999; Kozak, 2001; Yoon and Uysal, 2005).

In service sector, satisfaction is related to how much a consumer likes or dislikes a service or product after experiencing it (Frey and Daly, 1989; cited in Sukiman et al., 2013). Tourist satisfaction is very important for tourism destinations because it affects the selection of destination and more important decision to revisit. 


\section{GEOGRAPHICAL POSITION OF VRANICA TOURIST DESTINATION}

Mountain area of Vranica is located in the central part of Bosnia and Herzegovina. According to Katzer's research, group Vranica (Fig. 1) is the central Palaeozoic core, with total or partial development of Carbon, Silurian and Devonian geological formations in which, in addition to Vranica belong: Bitovnja, Pogrelica, Zec-planina, Dobruška i Krušićka mountain. In geomorphological terms, Vranica belongs to the zone of central Dinarides, with strong fluvial erosion, fluvial- accumulative landforms and colluvial relief forms.In the administrative and political terms Vranica mountain area encompasses parts of several municipalities in Central Bosnia Canton, including: Fojnica, Travnik and Gornji Vakuf. Vranica formed a complex surface water springs, which is orographicaly divided into the basin of river Bosna and Vrbas.

Of surface flows best known is Jezernica, river that flows out of Prokoško Lake and from which arises river Fojnička that ends in Visoko as a left tributary of Bosnia. From hydrographic objects should to be mentioned Prokoško Lake, which is located on the southeast side of Vranica, at an altitude of 1636 meters the under highest peak Nadkrstac, and is among the highest mountain Lakes in Bosnia and Herzegovina. Pedogeographical position is determined by the presence of different types of soil within hydromorphic section of the river valleys, and automorphic soils, brown acid and podzolic in the mountainous area. In these physical-geographical conditions in the lowest altitudes forest communities of hornbeam and oak, sometimes with spruce to $1000 \mathrm{~m}$ above sea level are found. Above this zone, dominates beech-fir forest, followed by a degraded beech forests and dwarf pine. In this high-altitude area a large

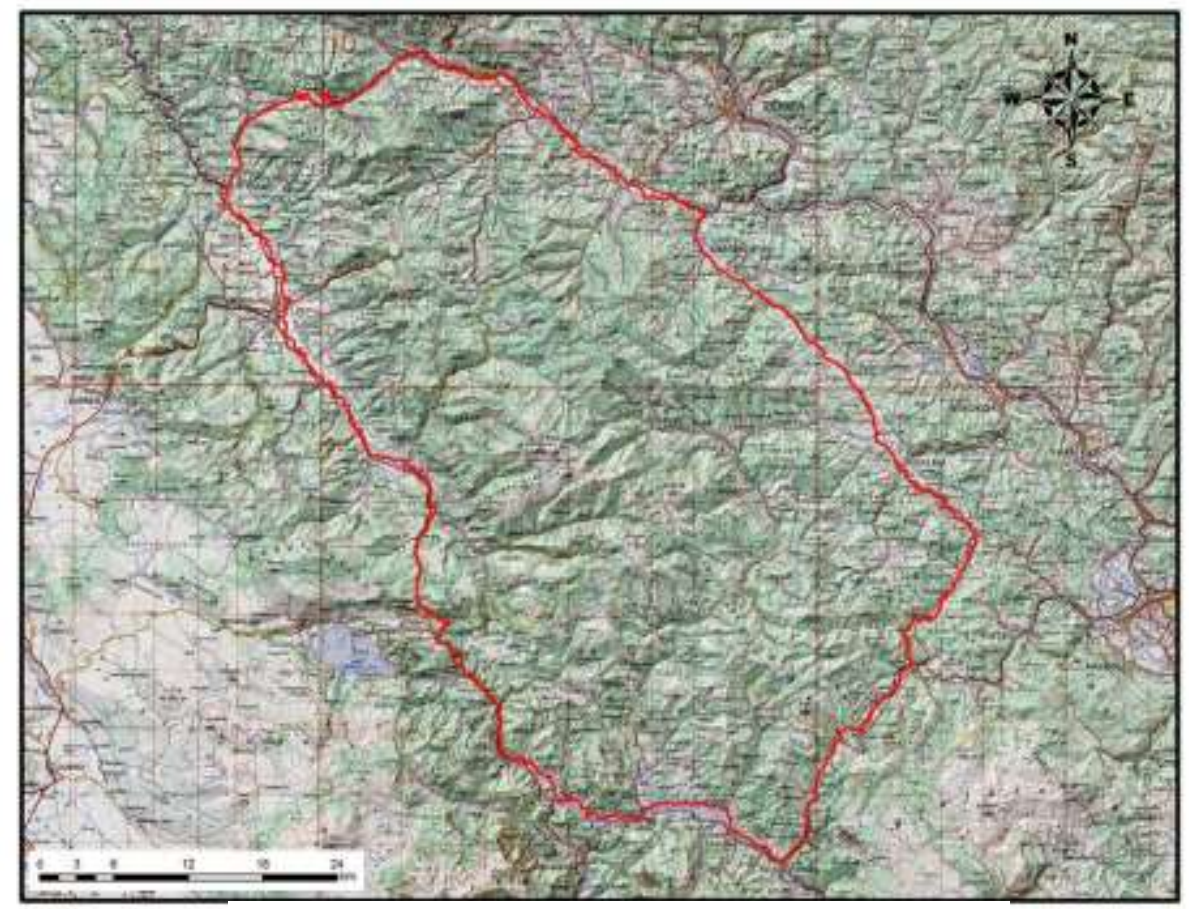

Fig.1. Geographical location of group Vranica 
number of endemic plant species is defined, such as mountain rose (Rhododendron hirsutum) or Vranica rockbell (Edraianthus niveus). This area is also a habitat for various species of wildlife such as bears, wolves, foxes, rabbits, grouse and others. Mountain Vranica and Prokoško Lake were perceived in terms of its natural value from the year 1954, when endemic species Triton was discovered. The Lake and its surroundings have been declared Regional Nature Park and become zones of strict protection in 1982. Within the CARDS program of development of the Emerald Network in South Eastern Europe, Prokoško Lake with Vranica is planned as one of the sites. During the year 2005 decision to protect Prokoško Lake through the legal category of natural monuments (III category according to IUCN), was made and established the borders of the area, protection zone, protection measures, activities in the protected area, the use of natural assets, etc.

\section{TOURIST ATTRACTIONS}

Evaluation of Vranica tourism attractiveness is based on attractive geocomplexes and geocomponents that form the basis for the development of tourism. In geological terms, mountain Vranica is a unique place that abounds in a variety of rock types. Since it belongs to the largest silicate complex in Bosnia and Herzegovina, Vranica is attractive for scientists and researchers, but also for potential tourists. Based on the analysis of geological potential of this area, it was determined that the mountain Vranica can develop and affirm as a geological park, which would have a scientific-educational, but also a tourism function. Characteristic rock formations, crystals and minerals can be used in the education of tourists and visitors, but also used as a basis for the development of activities such as finding and extracting minerals and crystals on the ground, cleaning and storage of them etc.

Vranica has many attractive mountain ranges that are worth visiting. Characteristic terrain, diverse relief, sharp peaks and ridges and deep rivers and streams valleys is good basis for the development of sports and recreational tourism. This whole region is marked with old cattle and caravan routes that lead through Vranica, Zec-mountain, Bitovnja, Kalina and others. Vranica provides many opportunities for hiking. Some of the most attractive mountain routes are:

- $\quad$ Vranica, Prokoško jezero - Rosinj (5 peaks of Vranica total length $12.2 \mathrm{~km}$

- $\quad$ Rise to Nadkrstac from Radovina total length $6.7 \mathrm{~km}$

- $\quad$ Rise to Ločika peak, second highest Vranica peak

- $\quad$ Fojnica - Matorac - Poljana total length $11.3 \mathrm{~km}$

The main problem is lack of the necessary tourism infrastructure, marked trails, which is the main prerequisite for the development of serious hiking activity. Among the peaks suitable for recreational hiking and mountain biking are especially attractive climbs to the highest peak Nadkrstac and Ločika, Matorac and Vran-kamen. As an important element of the geomorphological features is cave Krupljanka which has great 
aesthetic value, due to the attractiveness of the cave channels and ornaments of great beauty but also scientific value. In this cave system springs the river Kruščica, at about 700 meters depth. The most important hydrographic elements of the mountain area of Vranica that has tourism potential are rapids and waterfalls, the source of the Vrbas, Jezernica and Dragača, Prokoško Lake etc. River Dragača (Fojnička) and Vrbas can be valorized through complementary sports and recreational tourism activities such as fishing. Many springs and wells effect on raising the attractiveness of other hydrographic motives. In the tourist evaluation of the motives, their yield, purity of water, environment and natural preservation of the environment are important. Hydrologic elements have recreation (fishing, kayaking, canoeing, etc.), aesthetic value, and as such may be integral parts of the tourism supply. The most important tourist attraction of Vranica mountain area is certainly Prokoško Lake (Fig.2.) which is usually the main motive for visiting this mountain. Prokoško Lake has great aesthetic value; belongs to the oldest geological core of the Bosnian Dinarides and is the habitat of the Alpine Triton, which is a relict and endemic species.

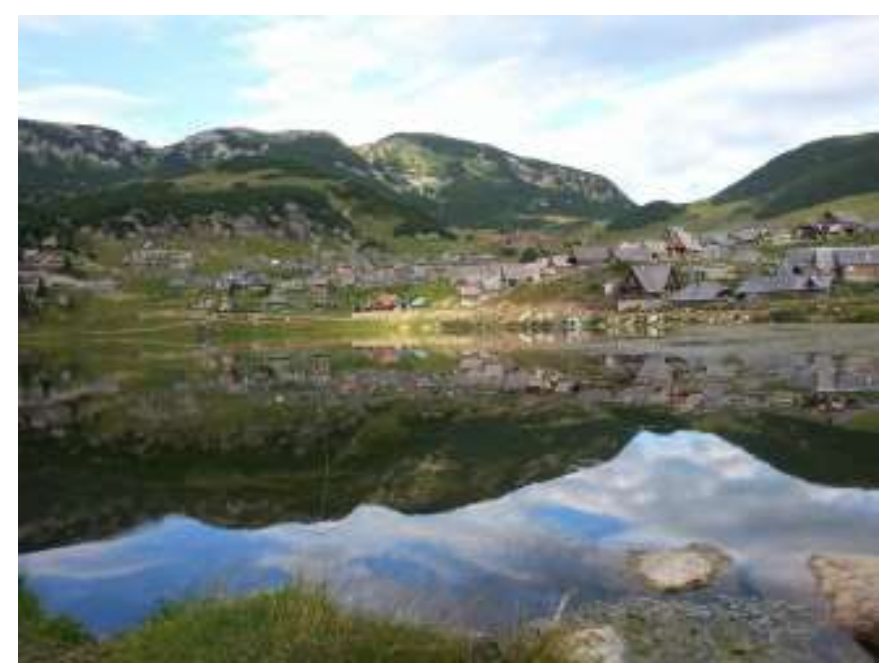

Fig.2. Prokoško Lake

Vranica is a mountain that is characterized by great wealth and diversity of the plant world, which provides a variety of conditions for tourism development. In terms of tourism development, forest vegetation is significant and has the advantage over the grassy ecosystems. There are three basic forms of a vegetation influence to human: recreational, aesthetic and ecological. Recreational characteristics, primarily forests increase the overall recreational value of the natural environment, and the presence of vegetation in the areas of recreation is necessary. The second impact of vegetation on tourism results from its aesthetic value. Aesthetic elements of vegetation attractivness are related to the shape and color of plant life. Mountain Vranica is famous for its various medicinal herbs, forrest berries - cranberries, wild raspberries, blackberries and 
wild strawberries, where cranberries have leading position. The forests and meadows are rich with fungi such as boletus, oyster mushroom etc.

Aesthetic properties of vegetation are connected to the landscape properties and rare relict and endemic species. As one of the most attractive species is certainly Vranica rockbell, which can be found below the peaks Krstaca. Vranica is the habitat of Alpine rose, mountain endemic plant that grows only in high mountain areas.

As a tourism destination, Vranica is widely recognized for its natural heritage and it is one of three pilot areas in Bosnia and Herzegovina, which have been selected for the EU network of protected areas project "Natura 2000". Mountain landscapes in Bosnia and Herzegovina have been the areas of intense cattle breeding since ever. Our mountains like Vranica are especially suitable for breeding of very productive sheeps. There are even today numerous herds of sheep called "pramenka" grazing on Vlašić, Vranica, Bjelašnica, Zelengora etc., whilst on other mountains graze herds of bosnian cows and horses. Mountain landscape of Vranica is also recognizable in their summer huts, so called "katuni". Next to this kind of settlements, usually built at higher altitudes (1.640 m Vranica, $1.700 \mathrm{~m}$ Maglić), occur special ecosystem (alpine dock, good king Henry, false helleborine, nettle).

\section{OBJECTIVES AND RESEARCH METHODOLOGY}

The purpose of this research is to provide scientific contributions to the study of tourism supply evaluation of mountain areas in Bosnia and Herzegovina. The following objectives of the research on Vranica are defined:

- Identification of tourism supply on mountain Vranica

- Analysis of tourist mobility characteristics

- Analysis of tourists attitudes and opinions on the tourism supply

- Residents' perceptions towards tourism impacts

- Analysis of the attractiveness of tourist attraction rating by the local community and tourists

Methodological approach has been consisting of theoretical and empirical relevant scientific literature collection, collecting and processing data from various sources and documentation, field research with direct survey and observations of tourism spatial implications and environmental aspects.

The degree of tourists' loyalty to a destination is reflected in their intentions to revisit the destination and in their recommendations to others, therefore this paper investigates the main elements that can influence tourist satisfaction and positive word-of-mouth. In order to study the link between destination attributes and tourist satisfaction, study collects data via questionnaire, to understand how mountain Vranica's attributes and services affect the tourist satisfaction, which allows identifying tourism supply current strengths and weaknesses. A face-to-face questionnaire was administrated to a sample of tourists and resident families, excluded second homeowners, in the area of Prokosi. 
Data collection was conducted in July and August 2016 at multiple locations on Vranica, on a sample of 210 tourists and residents (106 local residents and 104 tourists). The survey included respondents older than 18 years and statistical analysis was conducted in SPSS. The questionnaire for tourists and local residents were divided into two parts: the first part contains same socio-demographic and economic characteristics of the respondent as well as country of origin for tourists and marital status for residents.

Second part of the local's questionnaire contains 11 questions regarding the residents' opinion on tourism development; tourist's questionnaire contains 12 questions regarding their motives and means of arrival, opinion on tourist materials and available online information etc. Both residents and locals answered a question about attractiveness of tourist motives on Vranica using Likert scale 1-5. Tourist's questionnaire has one more question regarding the elements of tourism supply.

\section{RESULTS OF THE STUDY}

Of the total number of 210 respondents (106 local residents and 104 tourists), 65\% of locals and $68 \%$ of tourists were male. The age of local respondents varies from 19 to 77 and tourists from 21 to 65 years old. The research included tourists' country of residence, length of stay and mean of transport to the destination. International tourists from more than 12 different countries were represented. The largest proportion of participants $(37.5 \%)$ were tourists from The Middle East (Kuwait, Jordan and Saudi Arabia). It is important to emphasize, that this study does not include day visitors to the area nor visitors passing through. Domestic tourists accounted for the second largest $(30.8 \%)$, while the rest were from neighboring countries and Europe. Countries with the largest numbers of international tourists were Austria (5.8\%), Czech Republic (4.8\%), The Netherlands (3.8\%), Slovenia (3.8\%) and Germany (2.9\%). Approximately $43 \%$ of tourists are college-graduated. The biggest proportion of locals (59\%) said that they finished high school and 31\% primary school. The analysis also reveals that the largest proportion $(72 \%)$ of the tourists confirmed that they are employed, whereas largest share of locals are engaged in farming (24\%), cattle breeding $(25 \%)$ and forestry $(21 \%)$. Recently, as the results have shown, tourist function is gradually replacing silvicultural and agricultural activities in the area (18\% local respondents are employed in tourism sector). Due to their attractiveness, Vranica as many mountains in our country became a popular tourism destination especially among tourists from the Middle East. The Middle East is world's fastest-growing outbound travel with a 9\% increase in outbound trips in 2015. These are among the findings in the ITB World Travel Trends Report $2015 / 16$, which is produced by tourism consultancy IPK International on behalf of ITB Berlin, the world's leading travel trade show.

Besides Saudi Arabia, the United Arab Emirates (UAE), Qatar, Kuwait are the most attractive outbound market in the region and are characterized by high spending and long trips. Moreover, they tend to go on long trips, with an average trip lasting 10 and 
more nights. Research showed significant proportion of high-earners from the Middle East (about 35\%) under the age of 40 (averaging 36 years old). On Vranica, tourist from the Middle East stayed more than 6 days and spent between 50 and 100 EUR per day. Guests from the Middle East are a different type of tourist with priorities on nature and beautiful landscapes. A special emphasis is placed on satisfying religious needs and to respond to their customs and traditions, which makes Bosnia and Herzegovina suitable tourist destination for them. The analysis also reveals that the largest proportion (72.1\%) of tourists is employed with monthly income more than 1200 EUR $(25 \%)$. Second largest share (19.2\%) reported that they monthly income is between 800 and 1000 EUR. Car was the dominating means of transportation to Vranica. Almost half of the questioned tourists (48\%) used the own car, and about $52 \%$ came by organized transportation. Almost all tourists who came by organized transportation used services of travel agencies (46\%). About $35 \%$ of the respondents visited this area for the first time, and as many as $28 \%$ made their second visit and $14 \%$ their third visit. In the survey, the respondents were to indicate how likely are they re-visiting this destination. Approximately 52\% stated that they will visit Vranica again and 25\% will maybe come again. As already indicated, Vranica is widely known for its natural heritage and beautiful landscape. It was not surprising that $85 \%$ of the respondents consider that landscape differentiates Vranica from other tourist destinations. Personal recommendation was the most important source of information for nearly $43 \%$ of tourists, while 37\% chose internet. Generally, in Europe, personal recommendations rule when it comes to getting travel tips. Internet has risen to be the second biggest source of trip planning, while more traditional sources such as travel agencies and traditional media (TV, radio, newspapers, and magazines) are losing out. Almost 95\% of respondents stayed in private accommodation.

Apart from the private accommodation and mountain huts, there is no other accommodation in the area of Prokoško Lake on Vranica (hotels, youth hostels and camps etc.). Hotels are located in the area of Poljana and Fratarske Staje. There is no official statistics for mountain Vranica. According to the officials of Fojnica Municipality, it is estimated that over 50.000 tourists visit area of Poljana and Fratarske Staje and nearly 20.000 visited area of Prokoško Lake. Lack of tourism promotional materials is a huge problem in this destination. All respondents said that they didn't get a brochure or a travel guide about this destination. Without promotional material, destination fails to reach its target groups, which reflects on the number of tourists. Nearly $40 \%$ of tourists would like to get more information about the environment and $30 \%$ wants information on sightseeing tours and local gastronomy. According to the survey data, the most important motive when deciding to visit the area were rest and relaxation $(42.5 \%)$ and beauty of nature and landscape $(35.5 \%)$. Only $6 \%$ of the respondents stated fun and new experience as a motive of their visit. The questionnaire contained one question that required the respondents to rate attractiveness of 11 tourist attractions. (Table 1) They could also add other attraction. Most popular tourist attraction with highest rate was Prokoško Lake (mean $=4.49$; st. Deviation $=.776$ ). 
Locals rated Prokoško Lake slightly different $($ mean $=3.73$; st. Deviation $=1.303$ ), because they are not satisfied with its preservation and cleanliness. This indicates that tourism development is concentrated in the area of Prokoško Lake and shows that tourists were not familiar with most of tourist attractions on Vranica. Large number of tourists in one place causes many ecological problems and pressures on the environment. Natural processes of soil erosion and illegal building on the southwest shore of the Lake present serious ecological threat. In order to protect Prokoško Lake, but at the same time develop tourism it is necessary to promote other tourist attractions like Mountaneers Days, organize sightseeing tours to Ždrimački and Kozice waterfall etc. Most popular tourist attractions among local residents are mountain peaks Rosinj, Ločika and Krstac (mean $=4.72$; st. Deviation $=.785$ ), while $76 \%$ of tourists is not familiar with them. Also, Kozice waterfall (mean = 4.60; st. Deviation $=.832$ ), and endemic species Triton (mean $=4.10$; st. deviation $=1.353$ ), are well known and highly rated among locals, but almost tourists don't know anything about them. (83\% of respondents are not familiar with Kozice waterfall and 69\% with Triton). Results have shown that traditional cattle breeding is not part of tourism supply i.e. is not presented to the tourists, since $66 \%$ is not familiar with it. Herds of sheep "pramenka" and summer huts, so called "katuni" are attractive according to $56 \%$ of local residents. Festival Mountanieers Days is also not well presented to the tourists. According to this study, almost $60 \%$ of the tourists don't know about it, but it is important to emphasize that more than $37 \%$ who heard about it is very satisfied with it. Clearly, it is neccessary to promote this festival, since festival are increasingly being used as instruments for promoting tourism and boosting the local economy.

Table 1. Tourist and residents satisfaction with tourist attractions

\begin{tabular}{|l|r|r|r|r|}
\hline \multirow{2}{*}{\multicolumn{1}{|c|}{ Tourist attraction }} & \multicolumn{2}{|c|}{ Tourists } & \multicolumn{2}{c|}{ Local residents } \\
\cline { 2 - 5 } & Mean & $\begin{array}{c}\text { Std. } \\
\text { Deviation }\end{array}$ & Mean & $\begin{array}{c}\text { Std. } \\
\text { Deviation }\end{array}$ \\
\hline Prokosko lake & 4.49 & .776 & 3.73 & 1.303 \\
\hline $\begin{array}{l}\text { Peaks: Rosinj, Locika and } \\
\text { Krstac }\end{array}$ & 5.67 & .645 & 4.72 & .785 \\
\hline Climate & 4.66 & .533 & 4.50 & .841 \\
\hline Zdrimacki waterfall & 5.82 & .650 & 4.65 & .587 \\
\hline Kozice waterfall & 5.63 & .976 & 4.60 & .832 \\
\hline Krupljanka cave & 6.00 & .000 & 4.83 & .408 \\
\hline Fratarske Staje- Poljana & 5.92 & .411 & 4.18 & 1.021 \\
\hline Triton - endemic speices & 5.50 & .881 & 4.10 & 1.353 \\
\hline Traditional cattle breeding & 5.35 & 1.050 & 3.72 & 1.391 \\
\hline Festival Mountanieers Days & 5.41 & .820 & 4.23 & 1.017 \\
\hline Landscape & 4.89 & .538 & 4.52 & .789 \\
\hline
\end{tabular}


During the survey, tourists were asked to rate 17 different elements of tourism supply on mountain Vranica, which affect tourist satisfaction, in order to identify the current strengths and weaknesses of the tourism supply (Table 2). Among the satisfying factors, we can pinpoint kindness of local population and their complaisance, as well as the preservation of the environment. Finally, we can list knowledge of foreign languages of employees in tourism, souvenirs, traffic availabilty, sports facilities and offer of excursions as dissatisfying factors.

One of the core elements of sustainable tourism is that the tourism industry takes into account the views and aspirations of the local community. Both residents and tourists were asked to what extent local community exploits full potential for tourism development of Vranica. Answers were similar (tourists - mean value 2.27; residents mean value 2.56;) and both sides think that Vranica has much more to offer. When local community is involved in the direction of tourism development it is more likely to become an active partner and take a particular stake in the development of the destination. Research results show that almost $26 \%$ of residents consider that they should take part in decision of the direction and scale of tourism development.

Table 2. Tourist satisfaction with the elements of the tourism supply of the destiantion

\begin{tabular}{|l|r|r|}
\hline Elements of tourism supply & Mean & Std. Deviation \\
\hline Kindness of local population & 4.37 & .745 \\
\hline Kindness of employees in tourism & 3.35 & 1.330 \\
\hline Complaisance & 3.74 & 1.088 \\
\hline $\begin{array}{l}\text { Knowledge of foreign languages of employees in } \\
\text { tourism }\end{array}$ & 1.46 & .925 \\
\hline Traffic availabilty & 1.67 & .918 \\
\hline Information prior to arrival in the destination & 2.59 & 1.040 \\
\hline Tourist signs in the area & 2.40 & .989 \\
\hline Souvenirs & 1.70 & .882 \\
\hline Pathways & 3.57 & 1.220 \\
\hline Preservation of the environment & 3.76 & 1.072 \\
\hline Facilities for children & 2.43 & 1.546 \\
\hline Accomodation facilities & 3.88 & 1.228 \\
\hline Sports facilities & 1.98 & 1.158 \\
\hline Possibility for adventure tourism & 3.62 & 1.078 \\
\hline Offer of excursions & 1.84 & 1.066 \\
\hline Value for money & 3.56 & 1.166 \\
\hline Overall rating of tourist destination offer & 3.61 & .924 \\
\hline
\end{tabular}

While the economic benefits of tourism are increasingly appreciated by local communities, excessive numbers of visitors may disrupt the local environment. Environmental aspects of tourism in destination are not entirely satisfying according to 
$39 \%$ of local residents. Also, $37 \%$ of residents consider that they should be taken into account when it comes to activities for environment conservation.

Only $15 \%$ of local residents are thinking about moving out. However, this fact doesn't mean that they are satisfied with the situation in their community. Almost all respondents spent their whole life on Vranica. Among them 37\% are older than 50, so moving out and change of occupation is not an option.

More active tourism development should be development strategy for this area according to $84 \%$ of the respondents, although only $15 \%$ considers financial investment in tourism. Little interest in financial investment is connected to their low income and age ( $82 \%$ of the respondents have monthly income less than 400 EUR). In general, local respondents recognize the positive economic benefits of tourism (mean value 4.50). In particular, respondents do not agree on saying that tourism attracts more investments and spending to Vranica (mean value 2.24). However they also do not believe that tourism causes an increase in life standard (mean value 2.54), mainly because, they also partially agree with the idea that tourism benefits only small groups.

Respondents agree on the fact that tourism causes more positive than negative environmental impacts (mean value 4.25). In general, residents do not perceive that tourism provides an incentive for the conservation of natural resources (mean value 1.97), although traffic congestion, noise, and pollution are not caused due to tourism development (mean value 1.90). With respect to the socio-cultural aspects of the tourism impacts, we can note that local residents, consider the experience of meeting tourists from all over the world, and from abroad, a valuable happening ("Meeting tourist is a valuable experience", mean value 4.16). Local resident, on average does not perceive tourist's presence to cause a decrease in quality of life ("Tourism causes a lower quality of life", mean value 1.64) and tourism to cause an increase in crime problems ("Tourism causes security and crime problems", mean value 1.90). What is important to note is that the locals are more in agreement with the fact that the contact with tourists is a positive experience and, therefore, they also believe that it is an opportunity to enhance tourist's interest in local culture.

\section{CONCLUSION}

This paper analyzes the effects of Vranica mountain destination attributes on the generation of tourist satisfaction as well as residents perception towards tourism impacts. From this research, it comes out that tourist satisfaction depends on a complex process where the role of each actor is fundamental. In order to collect data, a face-toface questionnaire was administrated to total number of 210 respondents (106 local residents and 104 tourists) in the area of Prokosi. Data collection was conducted in July and August 2016. It is important to emphasize, that this study did not include day visitors to the area nor visitors passing through. Vranica is widely known for its natural heritage and beautiful landscape, so it was not surprising that Vranica as many 
mountains in our country became a popular tourist destination especially among tourists from the Middle East.

Personal recommendation was the most important source of information for nearly $43 \%$ of tourists and almost $95 \%$ of respondents stayed in private accommodation. Results showed that the most popular tourist attraction with highest rate was Prokoško Lake (mean $=4.49$; st. Deviation $=.776)$. Locals rated Prokoško Lake slightly different (mean $=3.73$; st. Deviation $=1.303$ ), because they are not satisfied with its preservation and cleanliness. Most popular tourist attractions among local residents are mountain peaks Rosinj, Ločika and Krstac (mean $=4.72$; st. deviation $=.785$ ), while $76 \%$ of tourists is not familiar with them. Results have shown that traditional cattle breeding, Festival Mountanieers Days are not part of tourist offer i.e. are not presented to the tourists. Herds of sheep "pramenka" and summer huts, so called "katuni" are attractive according to $56 \%$ of local residents.

According to this study, almost $60 \%$ of the tourists doesn't know about Festival Mountanieers Days, but it is important to emphasize that more than $37 \%$ who heard about it is very satisfied with it. During the survey, tourists were asked to rate 17 different elements of tourist offer on mountain Vranica. Among the satisfying factors were kindness of local population and their complaisance, as well as the preservation of the environment. Most dissatisfying factors were knowledge of foreign languages of employees in tourism, souvenirs, traffic availabilty, sports facilities and offer of excursions.

Findings show that tourists visiting Vranica are not completely satisfied, supporting that Vranica still has not a clear destination image. In the case of mountain tourist destinations with similar features as Vranica, it can be concluded that tourism policies would be supported by the community only if they have a positive perceptions regarding environmental, economic, and socio-cultural impacts. Residents receiving direct economic benefit from tourism and perceiving positive socio-economic impacts are more willing to support tourism development during all year round.

This paper is limited in some regards. Only residents and summer tourists were included in this study, but it would be interesting to study second homeowners and winter tourists attitudes and perceptions on tourism development. Future research should focus on extending this research by conducting surveys on residents and tourists of other mountain tourism destination in Bosnia and Herzegovina. In this way, it would be possible to identify whether differences and similarities exist between mountain tourism destination of the whole country in order to create unique development strategy.

\section{REFERENCES}

1. Albu, R.G., Nicolau, L.C., 2010: Changing attitudes in tourism - a possible way to win the battlewith the current economic crisis, Bulletin of the Transilvania University of Braşov 3 (52), 201-206. 
2. Aguiló E., Rosselló J., 2005: Host Community Perceptions. A Cluster Analysis, Annals of Tourism Research, 32(4): 925-941

3. Andereck, K. L., Vogt, C. A., 2000: The Relationship between Residents' Attitudes toward Tourism and Tourism Development Options, Journal of Travel Research, 39, 27-36

4. Andereck, K.L., Valentine, K.M., Knopf, R.C., Vogt, C.A., 2005: Residents' perceptions of community tourism impacts, Annals of Tourism Research, 32 (4), 1056-1076.

5. Andiotis, K., 2005: Community groups' perceptions and preferences to tourism development. Evidence from Crete, Journal of Hospitality and Tourism Research, 29(1), 67-90.

6. Ap J., 1992: Residents Perceptions on Tourism Impacts, Annals of Tourism Research, 19: 665-690.

7. Balaguer, L., Cantavella, M., 2002: Tourism as a long-run economic growth factor: the Spanish case, Applied Economics, 34, 877-884.

8. Baysan, S. 2001: Perceptions of the environmental impacts of tourism: A comparative study of the attitudes of German, Russian and Turkish tourists in Kemer, Antalya. Tourism Geographies, 3 (2), 218-235, doi:10.1080/14616680010030284

9. Brehm, J.M., Eisenhauer, B.W., Krannich, R.S., 2004: Dimensions of Community Attachment and Their Relationship to Well-Being in the Amenity-Rich Rural West, Rural Sociology, 69(3), 405-429.

10. Budeanu, A. 2007: Sustainable tourist behaviour - a discussion of opportunities for change. International Journal of Consumer Studies, 31(5), 499-508, doi:10.1111/j.1470-6431.2007.00606.x

11. Brunt, P., Courtney, P., 1999: Host Perceptions of Sociocultural Impacts, Annals of Tourism Research, 26(2), 493-515.

12. Deery, M., Jago, L., Fredline, L., 2011: Rethinking social impacts of tourism research: A new research agenda, Tourism Management, doi:10.1016/j.tourman.2011.01.026

13. Dietrich, A., García-Buades, E., 2008: Locals Perceptions of Tourism as indicators of destination decline, Tourism Management, 30, 1-10.

14. Dogan, H., 1989: Forms of Adjustment: Sociocultural Impacts of Tourism, Annals of Tourism Research, 16, 216-236

15. Doswell, R., 1997: How effective management makes a difference, Oxford: Butterworth - Heinemann.

16. Doxey, G.V., 1975: A Causation Theory of Visitors-Residents Irritants: Methodology and Research Inferences, in Proceedings of the Travel Research Association, 1975, 6 ${ }^{a}$ Annual 23 Conference, Salt Lake City, 195-198.

17. Easterling, D., 2004: The residents' perspective in tourism research: a review and synthesis, Journal of Travel \& Tourism Marketing, 17(4), 45-62. 
18. Fallon, P., Schofiel, P., 2006: The dynamics of destination attribute importance, Journal of Business Research, 59(6), 709-713.

19. Frauman, E., Banks, S., 2011: Gateway community resident perceptions of tourism development: Incorporating importance-performance analysis into the limits of change framework, Tourism Management, 13(1), 128-140.

20. Garrod, F., Fyall, A., 1998: Beyond the rhetoric of sustainable tourism? Tourism Management, 19(3), pp. 199-212.

21. Gilbert, D., Clark, M., 1997: An Exploratory Examination of Urban Tourism Impact, with Reference to Residents Attitudes in the Cities of Canterbury and Guildford, Cities, 14, 343-352.

22. Goodwin, H., 2006: Measuring and reporting the impact of tourism on poverty, Cutting Edge Research in Tourism - New Directions, Challenges and Applications School of Management, University of Surrey, UK.

23. Gursoy, D., Jurowski, C., Uysal, M., 2002: Residents attitudes: a structural modeling approach, Annals of Tourism Research, 29, 79-105.

24. Haley, A.J., Snaith, T., Miller, G., 2005: The social impacts of tourism: a case study of Bath, UK, Annals of Tourism Research, 32(3), 647-668.

25. Haralambopoulos N., Pizan A., 1996: Perceived Impacts of Tourism: The Case of Samos, Annals of Tourism Research, 23(3), 503-526.

26. Huh, C., Vogt, C.A., 2008: Changes in residents' attitudes toward tourism over time: a cohort analytical approach, Journal of Travel Research, 46(4), 446-455.

27. Jafari, J., 2001: The scientification of tourism. In V. L. Smith and M. Brent (eds), Hosts and guests revisited: tourism issues of the 21 st century, edited by New York: Cognizant Communication Corporation, 28-41.

28. Jago, L., Fredline, L., Deery, M., 2006: Tourism in small communities: risk and benefits, Tourism Review International, 10(1-2), 91-101.

29. Jenkins, O. H., 1999: Understanding and measuring tourist destination images, International Journal of Tourism Research, 1, 1-15.

30. Jovičić, D. (2011). Socio-cultural Impacts of Contemporary Tourism. Collegium Antropologicum, 35 (2), 599-605.

31. Jurowski C., Uysal M., Williams R.D., 1997: A Theoretical Analysis of Host Community Resident Reactions to Tourism, Journal of Travel Research, 36(2), 311.

32. Jurowsky, C., Gursoy, D., 2004: Distance effects on residents' attitudes toward tourism, Annals of Tourism Research, 31(2), 296-312.

33. Kaltenborn, B. P, Nyahongo, J.W., Kideghesho, J. R., 2011: The attitudes of tourists towards the environmental, social and managerial attributes of Serengeti National Park, Tanzania. Tropical Conservation Science, 4 (2), 132-148.

34. Kandampully, J., 2000: The impact of demand Fluctuation on the Quality of Service: A Tourism Industry Example, Managing Service Quality, 10(1), 10-18. 
35. Kiriakidou, O., Gore, J., 2005: Learning by example: benchmarking organizational culture in hospitality, tourism and leisure SMEs, Benchmarking: An International Journal, 12(3), 192-206.

36. Lankford, S.V., Howard, D.R., 1994: Developing a Tourism Attitude Impact Scale, Annals of Tourism Research, 24(1), 121-139

37. Lee, C-K., Kang, S.K., Long, P., Reisinger, Y., 2010B: Residents' perceptions of casino impacts: A comparative study, Tourism Management, 31(2), 189-201.

38. Lee, C.-K., Kang, S., Reisinger, Y. , 2010A: Community attachment in two rural gaming communities: Comparisons between Colorado between Colorado gaming communities, USA and Gangwon Gaming Communities, South Korea, Tourism Geographies, 12(1), 140- 168.

39. Liu, J., Var, T., 1986: Resident attitudes towards tourism impacts in Hawaii, Annals of Tourism Research, 13(2), 193-214

40. Long, P., Perdue, R., Allen, L., 1990: Rural Resident Tourism Perceptions and Attitudes by Community Level of Tourism, Journal of Travel Research, 28 (3), 3-9.

41. Kozak, M. 2001: Repeaters' behaviour at two distinct destination, Annals of Tourism Research, 28, 784-807.

42. McCool, S., Martin, S., 1994: Community Attachment and Attitudes Toward Tourism Development, Journal of Travel Research, 32 (3), 29-34.

43. McGehee, N., Andereck, K., 2004: Factors Predicting Rural Residents' Support of Tourism, Journal of Travel Research, 43, 131-140.

44. Nash, R., Thyne, M., Davies, S. 2006: An investigation into customer satisfaction levels in the budget accommodation sector in Scotland: a case study of backpacker tourists and the Scottish Youth Hostels Association, Tourism Management, 27, 525-532.

45. Ogorelc, A., 2009: Residents' perceptions of tourism impacts and sustainable tourism development, International Journal of Sustainable Economy, 1(4), 373387.

46. Pedrana, M., (2013). Local Economic Development Policies and Tourism. An Approach to sustainability and culture, Regional Science Inquiry Jorunal, 5 (1), 9199.

47. Perdue, R., Long, P. \& Allen, L., 1987: Rural Resident Tourism Perceptions and Attitudes, Annals of Tourism Research, 14, 420-429.

48. Perdue, R., Long, P., Gustke, L., 1991: The Effects of Tourism Development on Objective Indicators of Local Quality of Life, in Travel and Tourism Association 22nd Annual Proceedings, 191-201. Salt Lake City: TTRA.

49. Ramdas, M., Mohamed, B., 2014: Impacts of Tourism on Environmenta Attributes, Environmental Literacy and Willingness to Pay: A Conceptual and Theoretical Review. Procedia - Social and Behavioral Sciences, 144, 378-391.

50. Ritchie, B.W., Inkari, M., 2006: Host Community Attitudes Toward Tourism and Cultural Tourism Development: The Case of the Lewes District, Southern England, International Journal of Tourism Research, 8(1), 27-44. 
51. Ryan, C., Gu, H., 2010: Constructionism and culture in research: understandings of the fourth Buddhist festival, Wutaishan, China, Tourism Management, 31(2), 167178.

52. Salleh, M., Omar, K., Yaakop, A.Y., 2013: Tourist Satisfaction in Malaysia, International Journal of Business and Social Science, 4 (5).

53. Samimi, J. A., Sadeghi, S., Sadeghi, S., 2011: Tourism and Economic Growth in Developing Countries: P-VAR Approach. Middle-East Journal of Scientific Research 10 (1), 28-32.

54. Sari, F.O. (2012). Socio-cultural approaches to tourism: A research on the 'Tourist' notion of young Turkish people. Sociology Mind, 2, 200-203.

55. Sharma, B., Dyer, P., 2009: An Investigation of Differences in Residents' Perceptions on the Sunshine Coast: Tourism Impacts and Demographic Variables, Tourism Geographies, 11(2), 187-213.

56. Sheldon P., Var T., 1984: Resident Attitudes to Tourism in North Wales, Tourism Management, 15: 40-47.

57. Sheldon, P.J., Abenoja, T., 2001: Resident attitudes in a mature destination: the case of Waikiki, Tourism Management, 22(5), 435-443.

58. Sukiman, M., Omar, S., Muhibudin, M., Yussof, I., Mohamed, B., 2013: Tourist Satisfaction as the Key to Destination Survival in Pahang. Social and Behavioral Sciences, 91, $78-87$.

59. Teye V., Sirakaya E., Sönmez S., 2002: Resident's Attitudes toward Tourism Development, Annals of Tourism Research, 29(3): 668-688.

60. Tosun, C., 2002: Host Perceptions of Impacts: A Comparative Tourism Study, Annals of Tourism Research, 29, 231-253.

61. Um, S., Crompton, J.L., 1987: Measuring Resident's Attachment Levels in a Host Community, Journal of Travel Research, 26(2), 27-29.

62. Vargas-Sánchez, A., de los Ángeles Plaza-Mejía, M., Porras-Bueno, N., 2009: Understanding residents' attitudes toward the development of industrial tourism in a former mining, Journal of Travel Research, 47(3), 373-387.

63. Vargas-Sánchez, A., Porras-Bueno, N., de los Ángeles Plaza-Mejía, M., 2011: Explaining residents' attitudes to tourism. Is a universal model possible? Annals of Tourism Research, 38(2), 460-480.

64. Williams, J., Lawson, R., 2001: Community issues and the resident opinions of tourism, Annals of Tourism Research, 28(2), 269-290.

65. Woosnam, K., Norman, W., Ying, T., 2009: Exploring the theoretical framework of emotional solidarity between residents and tourists, Journal of Travel Research, 48(2), 245-258.

66. Xia, W., Jie, Z. Chaolin, G., Feng, Z., 2009: Examining Antecedents and Consequences of Tourist Satisfaction: A Structural Modeling Approach, Tsinghua Science and Technology, 14, 397-406. 
67. Yoon, Y., Uysal, M., 2005: An examination of the effects of motivation and satisfaction on destination loyalty: a structural model, Tourism management, 26, 45-56.

68. Young, G., 1973: Tourism: Blessing or blight. Harmondsworth: Pelican/Penguin Books.

69. Yu, L., Goulden, M. 2006: A comparative analysis of international tourists' satisfaction in Mongolia, Tourism Management, 27, 1331-1342.

70. Zaei, E. M., Zaei, E. M., 2013: The Impacts of Tourism Industry on Host Community. European Journal of Tourism Hospitality and Research, 1 (2), 12-21. 